\title{
Retraction Note: Agricultural climate change and rural animation film application based on remote sensing images
}

\section{Zhengzhong Shen ${ }^{1}$}

Published online: 22 November 2021

C) Saudi Society for Geosciences 2021

Retraction Note: Arabian Journal of Geosciences (2021) 14: 613

https://doi.org/10.1007/s12517-021-06858-1

The Editor-in-Chief and the Publisher have retracted this article because the content of this article is nonsensical. The peer review process was not carried out in accordance with the Publisher's peer review policy. The author has not responded to correspondence regarding this retraction.

The original article can be found online at https://doi.org/10.1007/ s12517-021-06858-1.

Zhengzhong Shen

shen_zhengzhong@163.com

1 College of the Arts, Chongqing Technology and Business

University, Chongqing 400067, China 